\title{
Leiomyosarcoma of the inferior vena cava. A case report with a review of the literature
}

\author{
E. O. ADEYEMI \\ M.D.
}

\author{
V. SCHEJBAL \\ M.D.
}

The Department of Medicine, St Joseph's Teaching Hospital, Axstrasse 35, 4630 Bochum-Linden, West Germany, and The Department of Pathology, University Clinics (Bergmannsheil), Hunscheidtstrasse 1, 4630 Bochum, West Germany

\begin{abstract}
Summary
A patient with leiomyosarcoma of the inferior vena cava is reported and a total of 65 cases is reviewed.

\section{Introduction}

Leiomyomas have never been seen in arteries and rarely occur in veins (Wilder \& Lofti, 1971). Leiomyosarcoma on the other hand occurs in arteries and veins, especially the latter and predominantly the inferior vena cava (Kevorkian, Donald and Cento, 1973). The clinical features depend on the area occupied by the tumour and these include nonspecific lumbar or abdominal pain, deep venous thrombosis and the Budd-Chiari syndrome.

A further case is reported and the literature reviewed.

\section{Case report}

A 45-year-old housewife was admitted in July 1978 because of abdominal distension noticed 14 days previously, and pain in the right hypochondrium with radiation to the left hemithorax.

There was a past history of hysterectomy in 1973 because of uterine fibromyoma, and right mastectomy in 1975 for comedocarcinoma (T1NoMo) followed by radiation therapy.

In 1976 she complained of backache, for which she was treated in an orthopaedic clinic, where she developed pelvic and deep vein thrombosis of the right leg. A bone scintiscan done in 1977 was normal.

The physical examination showed pitting oedema of the legs, and ascites with prominent superficial veins, mainly on the right half of the abdomen and thorax. The blood flow was from below upwards and could be traced up to the right costal margin.
\end{abstract}

Correspondence: Dr med Edward Olubiyi Adeyemi, Department of Medicine, St Joseph's Teaching Hospital, Axstrasse 35, 4630 Bochum-Linden, West Germany, Tel 0234/4181
The jugular venous pressure was slightly raised, there was no cardiac murmur, and the blood pressure was $130 / 70 \mathrm{mmHg}$. The liver was felt $3-4 \mathrm{~cm}$ below the right costal margin and was tender. The spleen was not felt.

The chest, plain abdominal $\mathrm{X}$-rays and intravenous urography were within normal limits.

The pelvic examination and overall gynaecological evaluation were normal. The liver scan showed decreased and non-homogeneous hepatic radionuclide uptake, suggestive of liver cirrhosis. There was increased splenic uptake and splenomegaly.

The erythrocyte sedimentation rate was $2 \mathrm{~mm} / \mathrm{hr}$. Haemoglobin, red and white blood cells, differential blood and platelet counts were within normal limits. The prothrombin time (Quick) was 62\% (normal $80-100$ ), alanine and aspartate aminotransferase 103 and 138 respectively (normal $<15 \mathrm{mu} . / \mathrm{ml}$ ), alkaline phosphatase 54 (normal $<47 \mathrm{mu} . / \mathrm{ml}$ ), lactic dehydrogenase 426 (normal $<240 \mathrm{mu} . / \mathrm{ml}$ ), bilirubin 2.55 $\mathrm{mg} / 100 \mathrm{ml}$. The total serum protein was $57 \mathrm{~g} /$ litre (normal 67-87) with hypoalbuminaemia on electrophoretic strip. Hepatitis B surface antigen was negative. A working diagnosis of liver cirrhosis with stage one hepatic coma was made, and the corresponding treatment instituted.

There was a slight reduction in the amount of oedema, the bilirubin rose to $4.4 \mathrm{mg} / 100 \mathrm{ml}$ and the prothrombin time came down to $35 \%$. Invasive diagnostic procedures were not possible and she died 3 weeks after her admission.

\section{Post-mortem examination}

The inferior vena cava was enlarged, sausageshaped in its entire length, expanded to $6 \mathrm{~cm}$ proximally and $5 \mathrm{~cm}$ distally. It was easily separated from the surrounding tissue. The external surface and, particularly, the perivascular tissue showed no 
tumorous infiltration. Almost completely occluding the lumen was a friable yellowish-red tissue, in which were several fissure-like irregular canals (Fig. 1), the surface of which bore patches of coarse and fine nodulations. Blunt thrombus-like projections were found in many areas, extending into the veins draining into the inferior vena cava.

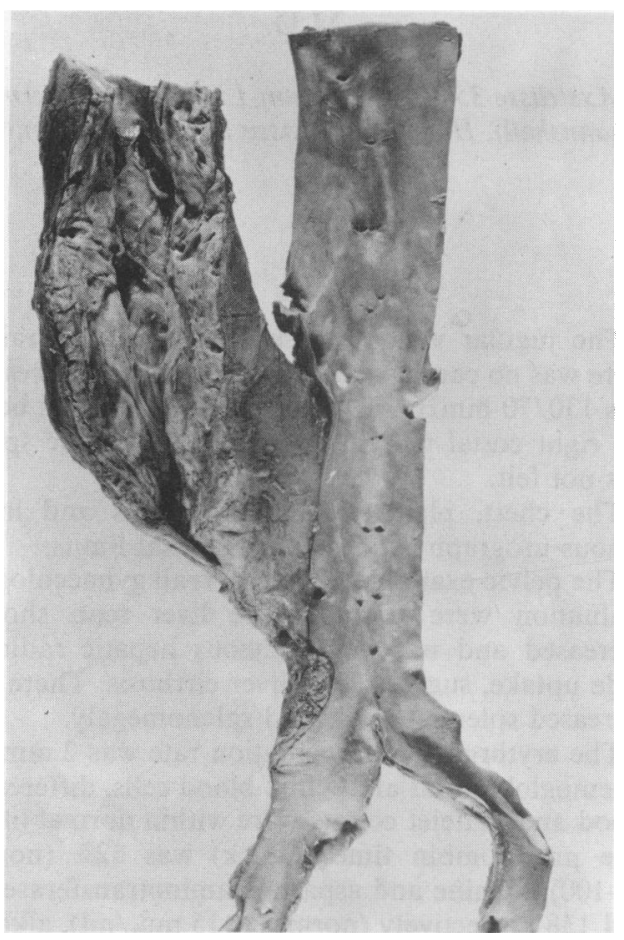

The tumour mass ended abruptly, shortly before the inferior vena cava joined the right atrium. Multiple old and organized thrombi with cord-like $c$. transformation of the large pelvic veins were present bilaterally. The lumen could hardly be recognized. Similar changes were seen in the medium-size retroperitoneal and femoral veins. The portal vein and its branches were unaffected. The hepatic cutsurface revealed gross congestion and destruction of the hepatic lobules (Fig. 2). There was no evidence of metastastatic breast cancer.

The microscopic examination (Fig. 3) of the tumour revealed atypical cells with nuclear polymorphy, high incidence of poor differentiation with giant cells and multinuclearity.

The liver histology showed zonal haemorrhage and extensive centrilobular haemorrhagic necrosis with evidence of tissue repair (Fig. 2). Also found were large nodular metastases each having central necrosis and a fibrous edge, between which were thin sheets of highly vascularized collagen fibres.

\section{Discussion}

Since the description in 1871 of a case of sarcoma of the inferior vena cava by Perl, 65 cases have been reported (Tables 1 and 2). Fifty-four of the 69 recorded cases were females but the reason for this. preponderance remains unexplained. It would be speculative to draw a connection between this tumour and oestrogen receptors on the smooth muscle membrane. Since $13(20 \%)$ of the patients had a history of uterine fibro-myoma during life or at post-mortem, it is tempting to regard this tumour as

Fig. 1. Macroscopic aspect of the leiomyosarcoma of the inferior vena cava. Also shown is the abdominal aorta.

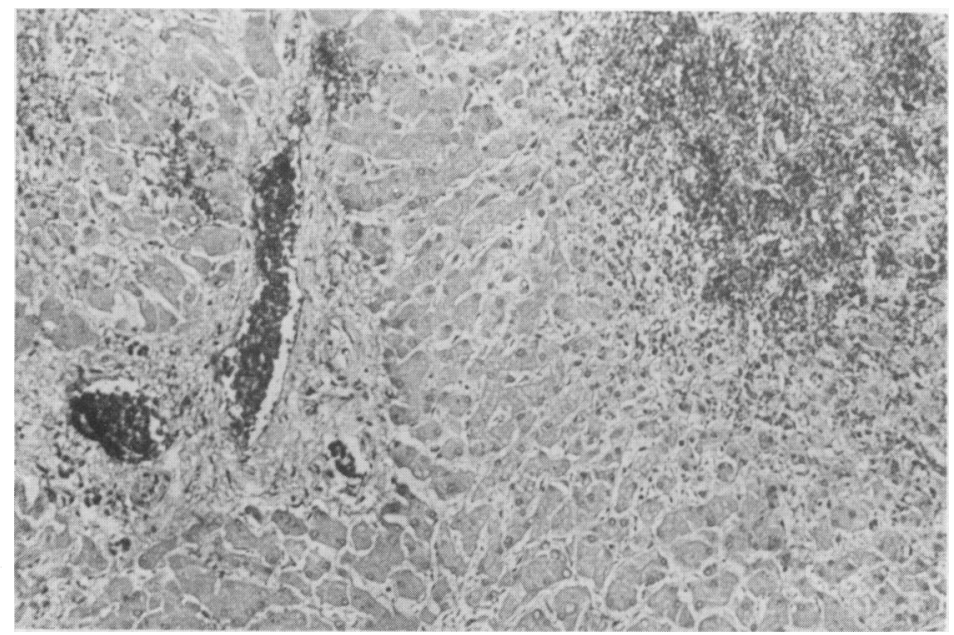

Fig. 2. Photomicrograph of the liver with zonal haemorrhage and destruction of the hepatic lobules (HE, $\times 250)$. 


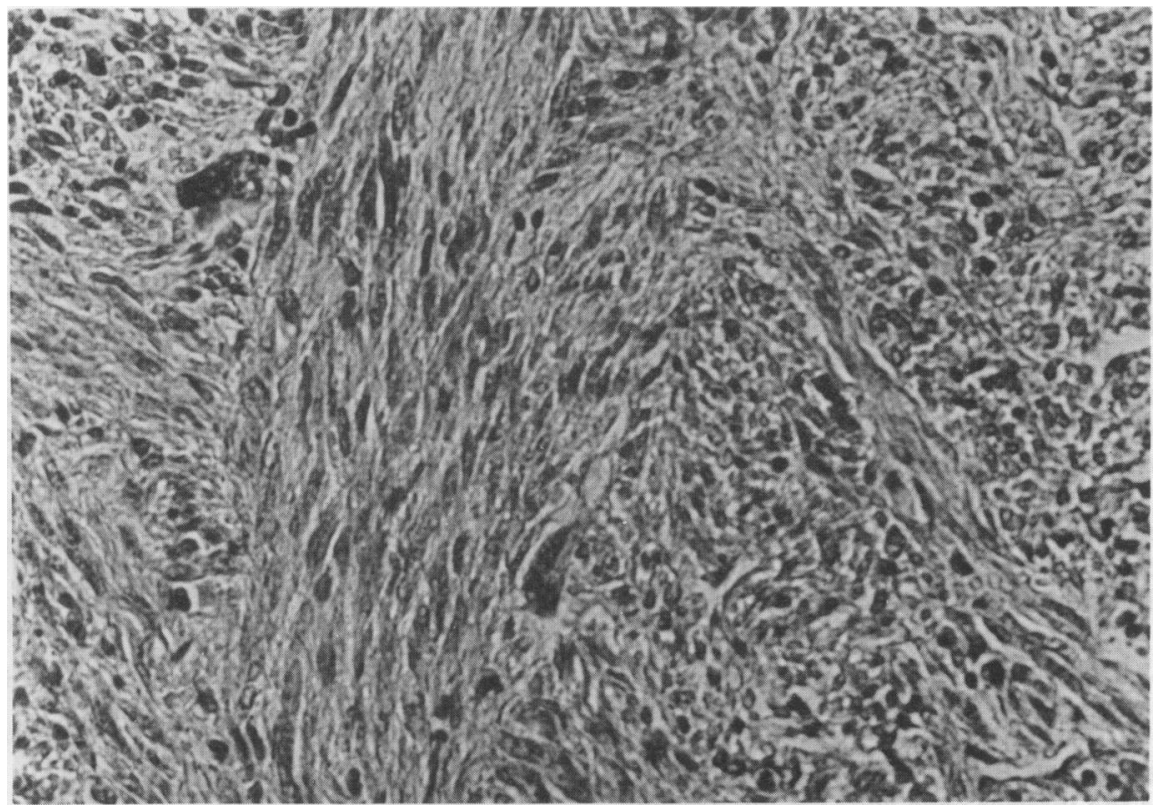

FIG. 3. Fusiform spindle-shaped cells of the tumour $(\mathrm{HE}, \times 760)$.

an intravenous leiomyomatosis, primary in the uterus (Jonasson, Pritchard and Long, 1966).

TABLE 1. Clinical features of 65 cases of leiomyosarcoma of the inferior vena cava (asterisked in reference list)

\begin{tabular}{ll}
\hline 54 females (83\%), & 11 males $(17 \%)$ \\
F/M ratio & $5: 1$ \\
Age range & $27-83$ years \\
Mean age of diagnosis & 55 years \\
Diagnosis during life & 35 cases $(54 \%)$ \\
Deep venous thrombosis/thrombophlebitis & 10 cases $(15 \%)$ \\
Budd-Chiari syndrome & 21 cases $(32 \%)$ \\
\hline
\end{tabular}

TABLE 2. Localization of tumour in 65 cases of leiomyosarcoma of the inferior vena cava

\begin{tabular}{lr}
\hline Upper-third & $8(12 \%)$ \\
Upper- and middle-thirds & $11(17 \%)$ \\
Middle-third & $19(30 \%)$ \\
Middle- and lower-third & $6(9 \%)$ \\
Lower-third & $9(14 \%)$ \\
Entire length & $9(14 \%)$ \\
Not specified & $3(5 \%)$ \\
\hline
\end{tabular}

The clinical signs depend on the localization of the tumour in the inferior vena cava. Leiomyosarcoma of the lower-third (below the renal veins) is generally associated with varying degrees of oedema of the legs with or without thrombosis (Brewster, Athanasoulis and Darling, 1976). Most (55\%) of the tumours reported (Table 2) originated in the middle-third (between the renal and the hepatic veins) with extension to the lower and/or the upper-third (above the hepatic veins).

Budd-Chiari syndrome is common when the upper-third is involved. The speed with which liver congestion occurs, depends on the rapidity of hepatic venous occlusion, hence differentiating acute and chronic forms of Budd-Chiari syndrome. In the acute form, there is severe right upper quadrant pain, nausea and vomiting, progressive hepatomegaly, at times with ascites, and death unavoidably occurs within 4 weeks in shock and uncontrollable hypotension with cyanosis (Onerheim \& Tesluk, 1961). In the chronic forms, the symptoms are irregular and nonspecific.

It is not uncommon for a patient to present after venous thrombosis with occlusion of the lumen and extension to other veins as in the present case. Ten (15\%) of the reviewed cases had venous thrombosis. Thus leiomyosarcoma of the inferior vena cava, although rare, should be included in the differential diagnoses of deep venous thrombosis. One of 35 patients referred to a surgical unit for thrombectomy had this condition (Spillner, Schlosser and Noeldge, 1976).

A palpable mass when present is of considerable help and was present in 19 (29\%) of the reviewed cases. Pain in the back, apparently due to the stretching of the vena cava by the tumour, is a 
common symptom in diseases unrelated to the inferior vena cava, and thus of no help to the physician. Our patient had lumbar pain and was referred to the orthopaedic unit, where she developed deep vein thrombosis of the right leg and therapyrefractory oedema of the legs.

The diagnosis was previously made only at postmortem examination, but with the introduction of modern techniques, diagnosis in life was achieved in $35(54 \%)$ of all hitherto reported cases. The diagnostic approach should include cavography during which cava and hepatic vein wedge pressure could be measured, liver scan, which may show poor radionuclide uptake, ultrasound and computed body tomographic studies. The liver biochemistry may be of considerable help in the acute form of the BuddChiari syndrome.

Most of the tumours were described as slowgrowing and invasion of adjacent organs is a late complication. Metastases, local and distant, especially to the lungs were found in about $42 \%$ of the cases.

Most, if not all, of the tumours localized in the upper-third of the inferior vena cava are not amenable to surgical treatment, whereas those of the middle- and lower-thirds can be managed surgically, although with variable results (Duke and Carlquist, 1968; Hopson, Burleson and Sherman, 1968; Melchior, 1928; Staley et al., 1967; Schildberg and Kuntz, 1977). Surgical resection was possible in 27 of the reviewed cases. Radiation and chemotherapy can be tried in unresectable tumours, and in addition to surgery when indicated. The value of the antioestrogen, tamoxifen has not been established.

\section{Acknowledgments}

We thank Professor Perings and Professor Koenn for their invaluable suggestions, Dr. $O$. Ojeniyi for translating the Russian article and Miss C. Massé for assisting with French translations.

\section{References}

*ABELl, M.R. (1957) Leiomyosarcoma of the inferior vena cava, review of the literature and report of two cases. American Journal of Clinical Pathology, 28, 272.

*Allan, J., BURNeTt, W. \& LEE, F.D. (1964) Leiomyosarcoma of the inferior vena cava. Scottish Medical Journal, 9, 352.

*Bailey, R.V., Stribling, J., WeitzneR, S. \& HaRdy, J.D. (1976) Leiomyosarcoma of the inferior vena cava. Report of a case and review of the literature. Annals of Surgery, 184, 169.

* Barbier, P., Scotto, J., Julien, C., Orcel, L. \& Caroli, J. (1968) Leiomyosarcome de la veine cave inferieure et syndrome de Budd-Chiari. Revue Medico-Chirurgicale des Maladies du Foie, du Pancréas et de la Rate, 43, 1.

*Barnes Hospital Clinico-Pathological Conference (1962) An unusual case of rapidly progressive hepatic failure. American Journal of Medicine, 32, 599.

*BEAIRD JR, J.B. \& SCOFIELD, G.F. (1962) Hepatic vein occlusion due to leiomyosarcoma primary in the inferior vena cava. Archives of Internal Medicine, 110, 435.
*Brewster, D.C., Athanasoulis, C.A. \& Darling, R.C. (1976) Leiomyosarcoma of the inferior vena cava: diagnosis and surgical management. Archives of Surgery, 111, 1081.

*CARDELL, B.S., MCGILL, D.A.F. \& Williams, R. (1971) Leiomyosarcoma of the inferior vena cava producing Budd-Chiari syndrome. Journal of Pathology, 104, 283.

* Case records of the Massachusetts General hospital (1971) New England Journal of Medicine, $284,967$.

* Case Records of the Massachusetts General hospital (1981) New England Journal of Medicine, 304, 162.

-COPE, J.S. \& HUNT, C.J. (1954) Leiomyosarcoma of the inferior vena cava. Archives of Surgery, 68, 752 .

*CouinaUd, C. (1973) Tumeurs de la veine cave inferieure. Journal de Chirurgie (Paris), 104, 411.

*Demoulin, J.C., Sambon, Y., Bandinet, V., Beaujean, M., JENKENS, J.M. \& DELVIGNE, J. (1974) Leiomyosarcoma of the inferior vena cava: an unusual case of pulmonary embolism. Chest, 66, 597.

*Deutsch, V., Fraenkel, O., Frand, U. \& Hulu, N. (1968) Leiomyosarcoma of the inferior vena cava propagating into the right atrium. British Heart Journal, 30, 571.

*DUBE, V.E. \& CARLQUIST, J.H. (1968) Surgical treatment of leiomyosarcoma of the inferior vena cava: Report of a case. American Surgeon, 37, 87.

*Evans, W.A. (1966) Leiomyosarcoma of the inferior vena cava. Medical Journal of Australia, 2, 419.

*GARIEPY, J.A. \& POPE, R.H. (1967) Leiomyosarcoma of the inferior vena cava. Connecticut Medicine, 31, 102.

*Goerttler, U., Noeldge, G., Baumeister, L., Boehm, N. (1977) Cavaverschluss-syndrome durch ein Leiomyosarkom der vena cava inferior. Radiologe, $17,350$.

*Guedon, J., Mesnard, J., Poisson, J. \& Kuss, R. (1970) Hypertension reno-vasculaire par leiomyosarcome de la veine cave inferieure: guerison de l'hypertension et survie de 2 ans apres intervention chirurgicale. Annales de Medicine Interne (Paris), 121, 905.

*HAAS, R. (1966) Primaeres Leiomyosarkom der vena cava inferior. Zentralblatt für Allgemeine Pathologie und Pathologische Anatomie, 108, 351.

*Hallock, P., Watson, C.J. \& Berman, L. (1940) Primary tumour of the inferior vena cava with clinical features suggestive of Chiari's disease. Archives of Internal Medicine, 66, 50.

*Harland, W.A., Clamen, M. \& Rodriguez, V.M. (19000) Leiomyosarcoma of the inferior vena cava with the clinical features of Chiari's syndrome. Canadian Medical Association Journal, 83, 1064.

*Hivet, M., PollleuX, J., Gastard, J. \& Hernandez, C. (1973) Sarcome de la veine cave inferieure. Nouvelle Presse Medicale (Paris), 2, 569.

*Hoffbrand, A.V. \& Lloyd-Thomas, H.G. (1964) Leiomyosarcoma of the inferior vena cava leading to obstruction of the tricuspid valve. British Heart Journal, 26, 709.

*Hopson JR, W.B., Burlison, P.E. \& Sherman, R.T. (1968) Leiomyosarcoma of the inferior vena cava. A case report. Annals of Surgery, 168, 290.

*JohANSEN, J.K. \& NiELSEN, R. (1971) Leiomyosarcoma of the inferior vena cava. Acta Chirurgica Scandinavica, 137, 181.

*Jonasson, O., Pritchard, J. \& LONG, L. (1966) Intraluminal leiomyosarcoma of the inferior vena cava. Cancer (Philadelphia), 19, 1311.

*Jurayl, M.N., Midell, A.I., Bederman, S., Gruen, J. \& O'BRIEN, P.H. (1970) Primary leiomyosarcoma of the inferior vena cava. Cancer (Philadelphia), 26, 1349.

*Justinian, F.R., Cohen, G.H., Roen, S.A., ARRibas, I. \& KUSHNER, D.S. (1973) Budd-Chiari syndrome due to leiomyosarcoma of the inferior vena cava. Digestive Diseases, 18, 337.

* KALITEEVSKY, P.F. (1961) Zabryushinnaya Leiomyosarkoma Ishodyashaya iz Stenki Nizhnei Poloi veni. Arkhiv Patologil, 23, 77.

*KALSBEEK, H.L. (1974) Leiomyosarcoma of the inferior vena cava. Archivum Chirurgicum Neerlandicum, 26, 35.

*KAPSinOw, R. \& BRIERRE, J.T. (1974) Leiomyosarcoma of the 
inferior vena cava. Journal of the Louisiana State Medical Society, 126, 400.

*LANDES, E. (1965) Leiomyosarcoma of the inferior vena cava. Dapim Refuiim, 24, 453.

*Laufer, A. \& Plaschkes, J. (1961) Primary leiomyosarcoma of the inferior vena cava. Pathologia et Microbiologia, 24, 72.

*LEU, H.J. \& NIPKOW, P. (1969) Malignant primary vein tumours. Angiologia, 6, 302.

*Lintner, F., Faust, U. \& Nowotny, Ch. (1978) Ein maligne entartetes primäres Leiomyom der Vena Cava Inferior (Leiomyosarkom) unter dem klinischen Bild des Chiari-Budd'schen Syndroms. Wiener Klinische Wochenschrift, 90, 485.

*Maillet, P., Barbier, B., BaulieuX, J., Boulez, J. \& Vauzelle, J.L. (1976) Leiomyosarcome dè la veine cave inferieure. Chirurgie. $102,658$.

*Melchior, E. (1928) Sarkom der Vena Cava Inferior. Deutsche Zeitschrift für Chirurgie, 213, 315.

*Nartowicz, E., Domaniewski, J. \& Wiecko, W. (1967) Leiomyosarcome de la veine cava inferieure. Traitement errone' de Cholecystite. Maroc Médical, 47, 339.

*NoeldGe, G., BoeHM, N., SPILlNeR, G. \& GoerTtLer, U. (1976) Leiomyosarkom der Vena Cava Inferior. Medizinische Welt, 27, 1747.

*Nyman, U., Hellekant, Ch., Jonsson, K. \& Granmayeh, M. (1979) Angiography in leiomyosarcoma of the inferior vena cava. Report of two cases. British Journal of Radiology, 52, 273.

*ONERHEIM, W.O. \& TeSLUK, H. (1961) Leiomyosarcoma of the inferior vena cava. Archives of Surgery, 82, 395.

*PERL, L. (1871) Ein Fall von Sarkom der Vena Cava Inferior. Virchow's Archiv für Pathologische Anatomie, 53, 378.

*RousSAK, N.J. \& HePplestone, J.D. (1950) Obstruction of the inferior vena cava by a leiomyosarcoma. Lancet, ii, 853.
*Spillner, G., Schlosser, V. \& Noeldge, G. (1976) Die akute Venenthrombose als Erstsymptom maligner Erkrankungen. Muenchner Medizinische Wochenschrift, 118, 1345.

*STAley, C.J., Valaitis, J., TRIPPEL, O. \& FranzblaU, S.A. (1967) Leiomyosarcoma of the inferior vena cava. American Journal of Surgery, 113, 211.

*STUART, F.P. \& BAKER, W.H. (1973) Palliative surgery for leiomyosarcoma of the inferior vena cava. Annals of Surgery, 177, 237.

*SCHILDbERG, F.W. \& KUNTZ, R.M. (1977) Leiomyosarkome der Vena Cava Inferior. Thoraxchirurgie, 25, 28.

*TEgTMEYER, C.J. \& BUSCHI, A. (1977) The angiographic diagnosis of leiomyosarcoma of the inferior vena cava. Radiology, 122, 683.

*Varela-Duran, J., Oliva, H. \& Rosal, J. (1979) Vascular leiomyosarcoma. The malignant counterpart of vascular leiomyoma. Cancer (Philadelphia), 44, 1684.

*Vercelli-Retta, J., LASSUS, M., Ponce, R. \& JauRena, J. (1979) Leiomyosarcoma of the inferior vena cava, Budd-Chiari syndrome and multiple endocrine morphological alterations. Vasa, 8 , 60.

*WILDER, J.R. \& LOFTI, M.W. (1971) Leiomyoma of the saphenous vein. Postgraduate Medical Journal, 50, 154.

*WRaY JR, R.C. \& Dawkins, H. (1971) Primary smooth muscle tumours of the inferior vena cava. Annals of Surgery, 174, 1009.

*Zaitsev, I.G. \& DZhabarow, F.I.A. (1975) Leiomyosarcoma of the inferior vena cava. Khirurgiya (Moscow), 8, 111.

*Zebro, T., Tomasik, B. \& JAsZCZ, W. (1962) Klinisches Bild des Budd-Chiari Syndroms als Folge des bösartigen Leiomyoms der unteren Vena Cava. Zentralblatt für allgemeine pathologie und Pathologische Anatomie, 103, 20. 